\section{Painting the CANVAS}

\author{
Dhungana $V^{1}$, Sthapit $B^{1}$, Sigdel $B^{1}$ \\ ${ }^{1}$ Intern, Kathmandu Medical College, Sinamangal, Nepal
}

\begin{abstract}
Canvas - a platform where one can draw or paint anything. It is the stage where one can pour out his/ her mind and imagination. And the interesting thing is, it comes out different every time! Every mind forms a different picture when stood in front of a blank canvas. What do you think a medical student would use a canvas for?
\end{abstract}

Here is a chronicle of a group of medical students, who truly lived the definition of canvas. They did not limit it to a piece of cloth to tip out paint, but a dais to decant their thoughts, emotions and service.

Roughly four years ago, 9 medical students of Kathmandu Medical College sat together. A common question was haunting the 9 brains - "How are we different from our fellow students?" They were more inquisitive and simply not satisfied with reading voluminous medical books, listening to lectures of age worn professors, or cutting open a cadaver. They wanted more. And surprisingly the answer dawned from the simplest of task - a presentation on social aspects of life of PLWHA. They all realised that the medical college was the beginning of their life for dedication and service.

So they sat down and came to an idea - a canvas which was to be a platform for their thoughts and devotion, a platform for service. And hence began a group, a stage for medical students to conduct any health related activities on path of service to the community. And thence the dawn of CANVAS.

In the coming days, the purpose of CANVAS broadened. It was now not just for service, because soon those medical students realised that it was as much of a platform for learning as it was for serving. The first lesson was establishing a legal identity, so that its service would be recognised. So after 6 months of sweat and hard work, from drafting proposals, writing constitution and bylaws, to countless visits to government offices and lawyers, CANVAS was registered on 13 October 2006. It was now a national level, not for profit organisation recognised by the government of Nepal. The three authors here were among the 9 founder members of CANVAS.

Then CANVAS started its steps to service, and each was a new lesson for us. We began by carrying out different health related activities. And proudly, every time it was a success. By second year, we had done a free health camp, a blood donation programme, two studies, a school health programme and numerous smaller events. Not that all the activities done were flawless, but every step was good enough to tech us some lessons. Our first free health camp at Kapan taught us about proper planning and work division, when so much work was left pending till the last days due to uneven work distribution. Nevertheless it was a triumph, when we crossed our estimated number of patients from 600 to more than 1000 and sent them back home with a contended smile. Our first blood donation programme also taught us something - that too many cooks spoil the broth! We had chosen our campus premises to conduct the event and that flooded us with more volunteers than we needed, and even more blood donors, most of whom were also medical students. It was really encouraging that more and more juniors are now inclined towards social service. Our trip to Barabise to evaluate the efficiency of the female community health volunteers (FCHV) enlightened us to the most effective system of health - the Primary Health Centre. The difference that an FCHV, a barely literate village woman, can make on the health standards of her village is unbelievable. It made us believe that to solve simple problems, we need simple answers. And we were proud to score full marks on community medicine viva voce, only for perfectly describing the role of FCHVs. Good deeds have hidden benefits sometimes!

Correspondence

Dr. Vivek Dhungana

Intern, Kathmandu Medical College

Sinamangal, Kathmandu

E-mail: vivekdhungana@hotmail.com 
And at the end of all programmes big and small, the round gathering, with coffee or drinks in hands and a question "What next?" always kept us together and moving. Examinations were the only periods of hibernation, as these notorious troublemakers deprived us of all our regular activities, including sleep!

CANVAS has given us as much as we have offered others via it. These four years are full of memories of countless discussions and small and big events enriching us with qualities of leadership, team spirit, innovativeness, perseverance, and self awareness. We began CANVAS from scratch and today it stands tall. It all began with building a castle in the air, of 9 students dreaming to build an independent platform for their activities. But the castle stood tall, because we built the base below it as strong as anything. In the end is always true that, it is not wrong to build castles in the air - that is where they should be, now just build the base below it. A simple group of medical students who only wanted to be of some help to the community went on this far so as now each member of the team is individually capable of leading new projects by themselves effectively. And yes, now we stand out from the crowd because we lived by our dreams.

Today as we are on verge of our internship, we know that now we are on to begin our new journey, of newer height of service in and outside the capital. We are now moving in different directions but not dissolving CANVAS. As the members spread their wings, the painting grows larger. More medical students will enter with their aspirations. The journey will continue - with new members and their newer acts of service to the community. Each of them would add a different stroke of fresh paint on CANVAS. 